\title{
HYDROGEN PRODUCTION AND DEGRADATION OF CELLULOSE BY ANAEROBIC DIGESTED SLUDGE
}

\author{
Jiunn - Jyi LAY ${ }^{1}$ and Tatsuya NOIKE ${ }^{2}$ \\ ${ }^{1}$ Member of JSCE, Dr. Eng., Assistant Professor, Dept. of Safty, Health, and Environ. Eng., National Kaohsiung \\ First University of Science and Technology (1, University Road, Yanchau, Kaohsiung, Taiwan, R.O.C.) \\ 2 Member of JSCE, Dr. Eng., Professor, Dept. of Civil Eng., Tohoku University (Aoba 06, Sendai 980-8579, Japan)
}

Studies were conducted to investigate the $\mathrm{H}_{2}$ production and degradation of microcrystalline cellulose by pretreated mesophilic digested sludge. Kinetic responses confirmed that the results of this study were highly reliable. Characteristics of the sludge converting the cellulose into $\mathrm{H}_{2}$ was similar to that of anaerobic sporeforming bacteria of the genus Clostridium. The results obtained emphasize that lag-period times of metabolites production depended upon initial cellulose concentration. When the cellulose exceeded $25 \mathrm{~g} / \mathrm{L}, \mathrm{H}_{2}$ significantly inhibited the sludge's hydrogenic activity. Initial cellulose concentration notwithstanding, soluble carbohydrates accumulation was still an important factor in affecting production potentials of metabolites.

Key Words: boiling, cellulose, digested sludge, hydrogen, inhibition, alcohols, volatile fatty acids

\section{INTRODUCTION}

Hydrogen is an excellent alternative energy candidate for the future. Hydrogen is known as an efficient and inexpensive energy carrier due to its renewable, and nonpolluting nature ${ }^{1)}$. When it is burned with air, the only possible pollutant are nitrogen oxides derived from the air itself, and concentrations of these are generally lower than concentrations produced by other fuels ${ }^{2}$. When it is burned with pure oxygen, the only product is water and heat. The thermo-content by unit mass of liquid hydrogen is about 2.75 times greater than that of hydrocarbon fuels ${ }^{3}$. While hydrogen can be easily produced by water electrolysis, thermochemical and radiolytic processes ${ }^{4)}$, the processes are not very economic due to its intensive energy consumption and only in area where cheap electricity is readily available ${ }^{5)}$. Concerning the global environmental impacts, such as greenhouse effect and resource recovery, microbial hydrogen production from renewable biomass reduces the human dependence of fossil fuel, decreases carbon dioxide emission and recovers bioenergy $\left.{ }^{6)}, 7\right)$.

Due to wastewater treatment standards become more stringent, the amount of sewage sludge production has increased year-by-year, resulting in more complex sludge management and disposal problems ${ }^{8}$. This increase has led to sewage sludge being considered more as a resource such as energy, than as waste material ${ }^{9}$. Anaerobic digestion of the organic fraction of municipal solid waste (OFMSW), blended with sewage sludge, has received growing attention during the last few years ${ }^{10}$. The OFMSW may provide a plentiful source of inexpensive organic substrate for hydrogen producing fermentations, since it is composed of approximately $70 \%$ organic matter, with a paper fraction (i.e., cellulose and lignin) as its major component ${ }^{11), 12)}$. Cellulose is a major component and is the most abundant of the earth's biopolymer ${ }^{13}$. Biological conversion of cellulose into hydrogen apparently represents a partial answer to waste accumulation and the depletion of hydrocarbon fuels reserves and carbon dioxide release, as well as renewable energy sources ${ }^{14)-16)}$.

Hydrogen is a major intermediate in organic matter degradation in the digested sludge ecosystem ${ }^{17), 18}$. It is produced by fibrolytic and fermentative microorganisms and could be potentially re-utilized by the three hydrogentrophic microbial groups: methanogens, sulfate-reducers and acetogens. Interspecies hydrogen transfer between hydrogenproducing and hydrogen-utilizing microorganisms allows growth and activities of fermentative and hydrolytic microorganisms ${ }^{19}$. Some researchers have introduced natural anaerobic microorganisms, obtained from anaerobic digested sludge and sludge compost, to generate hydrogen from cellulose by mixed batch cultures ${ }^{16), 20}$. It also has been reported that cellulose itself can act as substrate for hydrogen production from anaerobic pure cultures ${ }^{15), 21), 22}$. However, only traces 
of hydrogen are usually evolved with continuous flow digesters due to the ubiquitous nature of hydrogen consumers ${ }^{19}$. If activity of hydrogentrophic bacteria containing in anaerobic digested sludge is inhibited, the sludge possesses significant capacities for the transformation of cellulose into hydrogen gas.

The inhibition of hydrogen consumers is essential for net hydrogen production, and for further scale-up and industrial application. The inhibition not only considers to be cost effective but also to bacterial characteristics ${ }^{23)}$. A simple boiling approach can be quickly performed in laboratory or field. When the digested sludge is exposed to boiling water exceeding 15 minutes, all non-spore-forming microorganisms will be inhibited/deactivated ${ }^{24)}$. Van Andel et al. ${ }^{25)}$ have been reported that the anaerobic spore-forming bacteria form an important part of acidogenic population performing acetate/butyrate fermentation. The review by Zajic et al. ${ }^{4}$ ) also indicate that the main anaerobic hydrogen-producing sporeformers are Clostridium sp. Preliminary experiments have successfully used a heat-pretreated digested sludge converting OFMSW into hydrogen gas, and demonstrate that the sludge possessed partial clostridial characteristics ${ }^{26)}$.

Such a phenomenon should be responsible for the metabolism observed with an inhibited/deactivated digested sludge. The following experiments were performed with boiling water as a hydrogentrophic bacterial inhibitor in small batch reactors for the production of hydrogen using microcrystalline cellulose as a model solid wastes, and an undefined consortium derived from anaerobic digester as inocula. The experiments were designed to (i) validate the stability of the inhibited digested sludge, (ii) evaluate the characteristics of hydrogen production, and (iii) describe the metabolism of the sludge under various cellulose concentrations.

\section{MATERIALS AND METHODS}

\section{(1) Experiment design}

Two runs of mixed batch experiments on the hydrogen formation of cellulose-degrading sludge were conducted in $120 \mathrm{~mL}$ glass serum vials. Four batches for the first run was performed using microcrystalline cellulose as the sole substrate at $12.5,25.0,37.5$ and $50.0 \mathrm{~g} / \mathrm{L}$, respectively. The second run was conducted to confirm the validity of the experimental results of the first run. Five batches were run using feed solution containing $10.0,20.0,30.0,40.0$ and $50.0 \mathrm{~g} / \mathrm{L}$ of microcrystalline cellulose, respectively. The detail experimental apparatus and procedure are as follows.

\section{(a) Seed microorganisms}

The digested sludge taken from a ten-liter laboratory digester was used to seed each batch reactor. The digester was operated at a temperature of $37 \pm 1{ }^{\circ} \mathrm{C}$ and a hydraulic retention time (HRT) of 20 days for over three years by being fed it with high-solid organic wastes. The solids concentration in it was maintained at $2-3 w t . \%$. Previous studies ${ }^{27)}$ demonstrated that the sludge contained in the digester had a high methanogenic activity on the treatment of the highsolids organic wastes. Before seeding, the sludge was brought to a 15 -minute boil to inhibit the bioactivity of hydrogentrophic bacteria ${ }^{26)}$.

\section{(b) Procedure}

The mixed batch experiments were performed under a mesophilic condition of $37^{\circ} \mathrm{C}$ using a glass bottle of $120 \mathrm{~mL}$ volume as a cellulose digester. A rotary cell culture apparatus with a rotation speed of $1.5 \mathrm{rpm}$ was used for mixing the contents of the digester. According to above mentioned, appropriate quantities of the digested sludge and microcrystalline cellulose (Avicel type Funacel powder, FC-500, AVC) were added to each digester, and subsequently supplemented with 1.0 $\mathrm{mL}$ of media. Each liter of media contained $200 \mathrm{~g}$ of $\mathrm{NH}_{4} \mathrm{HCO}_{3}, 100 \mathrm{~g}$ of $\mathrm{KH}_{2} \mathrm{PO}_{4}, 10 \mathrm{~g}$ of $\mathrm{MgSO}_{4} \cdot 7 \mathrm{H}_{2} \mathrm{O}, 1.0$ g of NaCl, 1.0 g of $\mathrm{Na}_{2} \mathrm{MoO}_{4} \cdot 2 \mathrm{H}_{2} \mathrm{O}, 1.0 \mathrm{~g}$ of CaCl $2 \cdot 2 \mathrm{H}_{2} \mathrm{O}$, $1.5 \mathrm{~g}$ of $\mathrm{MnSO}_{4} \cdot 7 \mathrm{H}_{2} \mathrm{O}$, and $0.278 \mathrm{~g}^{2} \mathrm{FeCl}_{2}$, which was slightly modified from Bahl et al. ${ }^{28}$. The capacity of each digester was then filled to 80 grams with distilled water. The $\mathrm{pH}$ of digester content was initially adjusted to around 7.0 with $1.0 \mathrm{~N} \mathrm{KOH}$ because the bioactivity of hydrogen-producing microorganisms is re-established rapidly on neutralization of the culture ${ }^{29}$. The medium $\mathrm{pH}$ was allowed to drop during batch fermentation. The fermentation then stopped upon hydrogen production reaching zero. Production of biogas was measured by the displacement of the water lubricated plunger of glass syringes of $5-50 \mathrm{~mL}^{30)}$.

\section{(2) Analytical methods}

The percentage of hydrogen in biogas was determined using a gas chromatograph (GC, Shimadzu 8A) equipped with a thermal conductivity detector (TCD) and a 2-m stainless column packed with Porapak Q. Nitrogen was used as the carrier gas at a flow rate of $30 \mathrm{~mL} / \mathrm{min}$. The methane and carbon dioxide was separated using a second GC-TCD of the same model with a 2-m stainless column packed with Porapak T. The detection limit of the TCD was $0.1 \%$ for hydrogen and methane. The concentrations of the volatile fatty acids (VFAs) were determined using a third GC of the same model with a flame ionization detector (FID) and a 2-m glass column packed with Unisole F-200. The ethanol, propanol and butanol were analyzed using a GC-FID of the same model with a 2-m glass column packed with Gaskuropack 54 . Helium was used as the carrier gas for the determinations of methane, VFAs and alcohols at a flow rate of $30 \mathrm{~mL} / \mathrm{min}$. The $\mathrm{pHs}$ of $0.5-\mathrm{mL}$ samples were determined by a TOA $\mathrm{pH}$ meter equipped with a GST-5425C probe. Carbohydrates concentration was measured by the phenol-sulfuric acid method using glucose as the standard. The concentrations of total solids (TS) and volatile solids (TVS) were determined by $10-\mathrm{mL}$ samples in $105^{\circ} \mathrm{C}$ and $600{ }^{\circ} \mathrm{C}$ ovens, 
Table 1 Stability and characteristicsof the inhibited sludge transferring variuos concentrations of microcrystalline cellulose into hydrogen.

\begin{tabular}{|c|c|c|c|c|c|c|c|c|}
\hline \multirow{2}{*}{\multicolumn{2}{|c|}{$\begin{array}{c}\text { Cellulose } \\
(\mathrm{g} / \mathrm{L})\end{array}$}} & \multirow[b]{2}{*}{$\mathrm{H}_{2}$} & \multicolumn{3}{|c|}{ Volatile Fatty Acids } & \multicolumn{3}{|c|}{ Alcohols } \\
\hline & & & Acetate & Propionate & Butyrate & Ethanol & Propanol & Butanol \\
\hline Run 1 & Run 2 & \multicolumn{7}{|c|}{ Production Potential (mmol/gCellulose) } \\
\hline & 10.0 & 2.21 & 2.53 & 0.32 & 2.01 & 1.93 & 3.01 & 5.61 \\
\hline \multirow[t]{2}{*}{12.5} & & 2.01 & 2.63 & 0.23 & 1.87 & 1.86 & 2.86 & 5.74 \\
\hline & 20.0 & 1.62 & 2.02 & 0.15 & 1.52 & 1.63 & 1.82 & 5.21 \\
\hline \multirow[t]{2}{*}{25.0} & & 1.56 & 1.32 & 0.10 & 1.36 & 1.69 & 2.00 & 5.00 \\
\hline & 30.0 & 1.53 & 1.51 & 0.09 & 1.23 & 1.52 & 1.02 & 4.21 \\
\hline \multirow[t]{2}{*}{37.5} & & 1.12 & 1.32 & 0.08 & 0.89 & 1.34 & 0.98 & 3.50 \\
\hline & 40.0 & 1.06 & 1.23 & 0.05 & 1.05 & 1.12 & 0.91 & 3.82 \\
\hline \multirow[t]{4}{*}{50.0} & & 0.45 & 0.70 & 0.04 & 0.82 & 1.21 & 0.70 & 2.81 \\
\hline & 50.0 & 0.55 & 0.76 & 0.04 & 0.69 & 1.16 & 0.78 & 2.62 \\
\hline & & \multicolumn{7}{|c|}{ Specific Production Rate (mmol/gVSS/d) } \\
\hline & 10.0 & 8.02 & 1.21 & 0.09 & 2.51 & 4.48 & 7.21 & 7.56 \\
\hline \multirow[t]{2}{*}{12.5} & & 8.93 & 1.41 & 0.04 & 2.50 & 4.16 & 7.00 & 7.38 \\
\hline & 20.0 & 11.40 & 2.51 & 0.62 & 2.78 & 3.22 & 5.51 & 6.52 \\
\hline \multirow[t]{2}{*}{25.0} & & 11.16 & 2.48 & 0.57 & 2.80 & 3.00 & 5.82 & 5.68 \\
\hline & 30.0 & 10.02 & 2.19 & 0.53 & 2.52 & 2.42 & 4.82 & 5.01 \\
\hline \multirow[t]{2}{*}{37.5} & & 8.44 & 2.00 & 0.42 & 2.50 & 2.50 & 4.92 & 4.76 \\
\hline & 40.0 & 6.00 & 1.82 & 0.18 & 2.22 & 2.99 & 5.02 & 4.49 \\
\hline \multirow[t]{4}{*}{50.0} & & 2.23 & 1.48 & 0.18 & 2.20 & 4.00 & 6.00 & 6.00 \\
\hline & 50.0 & 2.85 & 1.29 & 0.25 & 2.23 & 4.19 & 5.55 & 6.48 \\
\hline & & \multicolumn{7}{|c|}{ Lag-period Time (days) } \\
\hline & 10.0 & 3.79 & 3.32 & 3.91 & 4.43 & 5.43 & 5.79 & 5.42 \\
\hline \multirow[t]{2}{*}{12.5} & & 3.96 & 3.38 & 4.00 & 4.50 & 5.52 & 6.00 & 5.50 \\
\hline & 20.0 & 4.10 & 3.50 & 4.10 & 4.71 & 6.22 & 6.31 & 5.83 \\
\hline \multirow[t]{2}{*}{25.0} & & 4.20 & 3.60 & 4.20 & 4.80 & 6.51 & 6.50 & 6.00 \\
\hline & 30.0 & 4.21 & 3.70 & 4.12 & 4.84 & 6.52 & 6.78 & 6.09 \\
\hline \multirow[t]{2}{*}{37.5} & & 4.10 & 3.80 & 4.20 & 4.90 & 6.70 & 7.00 & 6.50 \\
\hline & 40.0 & 4.09 & 3.82 & 4.52 & 4.88 & 6.78 & 7.11 & 6.60 \\
\hline \multirow[t]{2}{*}{50.0} & & 4.30 & 4.00 & 4.60 & 5.10 & 6.90 & 7.20 & 7.00 \\
\hline & 50.0 & 4.41 & 4.12 & 4.52 & 5.20 & 7.00 & 7.34 & 7.12 \\
\hline
\end{tabular}

respectively, according to the procedures described in Standard Methods ${ }^{31}$.

\section{(3) Confirmation of the digested sludge characteristics}

To systematically characterize the nature of the digested sludge converting the cellulose into hydrogen gas, a modified Gompertz equation ${ }^{9)}$ was conducted to estimate production lag (day), rate ( $\mathrm{mmol} / \mathrm{gVSS} / \mathrm{d}$ ) and potential (mmol/gCellulose) of hydrogen, VFAs and solvents in a batch experiment.

$$
H=P \cdot \exp \left\{-\exp \left[\frac{R_{m} \cdot e}{P}(\lambda-t)+1\right]\right\}
$$

where $H$ is cumulative hydrogen production (mmol), $P$ is production potential (mmol), $R_{m}$ is maximum production rate, $(\mathrm{mmol} / \mathrm{d}), \lambda$ is lag-phase time (day), and $e$ is 2.718281828 . Subsequently, the specific hydrogen production potential ( $\mathrm{mmol} / \mathrm{gCellulose}$ ) was obtained by dividing $P$ by cellulose weight (gCellulose), while the specific production rate (mmol/ $\mathrm{gVSS} / \mathrm{d}$ ) was calculated by dividing $R_{m}$ by the dry sludge weight (gVSS). The parameters of Eq. (1) were estimated using the function of the "solver" in Microsoft Excel version 5.032). This program uses a Newton algorithm. Up to 100 iterations were used to converge sum of the square errors (SSE) between the experiment and the estimation to a minimum value. Starting parameter values were estimated using a builtin visual procedure based on a limited fit algorithm ${ }^{33)}$. Among the statistics reported by Wen et al. ${ }^{33)}$, the following were used to evaluate a fit: sum of the square errors (SSE), correlation coefficient $\left(r^{2}\right)$, standard errors (SE), 95\% confidence limits, and $t$-values of the parameters (ratio of parameter value to standard error).

\section{RESULTS AND DISCUSSION}

\section{(1) Stability of sludge converting cellulose into hydrogen and metabolites}

In order to quantitatively clarify stability of the inhibited mesophilic digested sludge, two-run batches were sequentially evaluated by changing the cellulose concentration from 12.5 to 50.0 and 10.0 to $50.0 \mathrm{~g} / \mathrm{L}$, 
respectively. Equation (1) was then used to fit the experimental data of each cumulative hydrogen/ metabolites production curve. The best values of the kinetic parameters in Eq. (1) were diagnosed by the same statistical approach that has been used elsewhere ${ }^{9)}$ 33),34), and are summarized in Table 1. All of the $t$ values and $r^{2}$ were larger than $t_{0.975}(9)=2.26$ (table value) and 0.90 , respectively, indicating that the parameters were taken to be statistically significant at a confidence interval of $95 \%{ }^{35}$. From a comparison of each individual parameters in Table 1, production potentials of hydrogen, VFAs and alcohols decreased with increase in cellulose concentration. Obviously, the hydrogenproducing microorganisms from the digested sludge used in run 1 was the same with that of run 2, demonstrating that seed microorganisms in the digester possessed high stability. An examination of Table 1 also reveals that highly reproducible values of kinetics parameters (i.e., potential, rate and lag-period) were obtained from the digester containing $50.0 \mathrm{~g} / \mathrm{L}$ cellulose for run 1 and 2 . This expression may become evident that the ability of digested sludge to generate hydrogen in a reproducible manner under heat-pretreated conditions allow us to use it for a continuous flow reactor generating hydrogen.

\section{(2) Metabolism of the cellulose degradation by the sludge}

Various microcrystalline cellulose concentrations (from 10.0 to $50.0 \mathrm{~g} / \mathrm{L}$ ) were performed to monitor the metabolites of the inhibited digested sludge consuming cellulose. There was little difference in nine batches of cellulose metabolisms. Example of $25.0 \mathrm{~g} / \mathrm{L}$ cellulose (Fig.1) shows the time course of the fermentation pattern, including (a) hydrogen percentage, (b) cumulative hydrogen production and $\mathrm{pH}$, (c) acetate, propionate and butyrate, and (d) ethanol, propanol and butanol, during the transition of inhibited mesophilic digested sludge converting cellulose into hydrogen. Fig.1a illustrates that except for initial inoculation, the biogas had a high value of hydrogen composition (50\%), and no methane was found based on the GC-TCD analysis throughout this study. Accordingly, boiling apparently inhibited the growth of hydrogentrophic bacteria contained in the sludge In Fig.1b, after an acclimation period of about 4 days, hydrogen produced rapidly and stopped after 8 days. During this period, the $\mathrm{pH}$ kept at around 7.0 (from initial to day 4 ) and suddenly dropped to a value of 5.3 (day 7). Similarly, the VFAs (Fig.1c) production began on day 4 until day $8-10$. This may suggest that the formation of hydrogen was accompanied by those of the VFAs when the digested sludge converted the cellulose into hydrogen. As observed for alcohols production, the production of ethanol, propanol and butanol (Fig.1d) began on day 5 - 6 and reached maximum levels. This metabolism was similar to that of pure culture of Clostridium sp. consuming carbohydrates ${ }^{36)-38)}$. The above findings led to the reasoning that the heat-pretreated digested sludge on
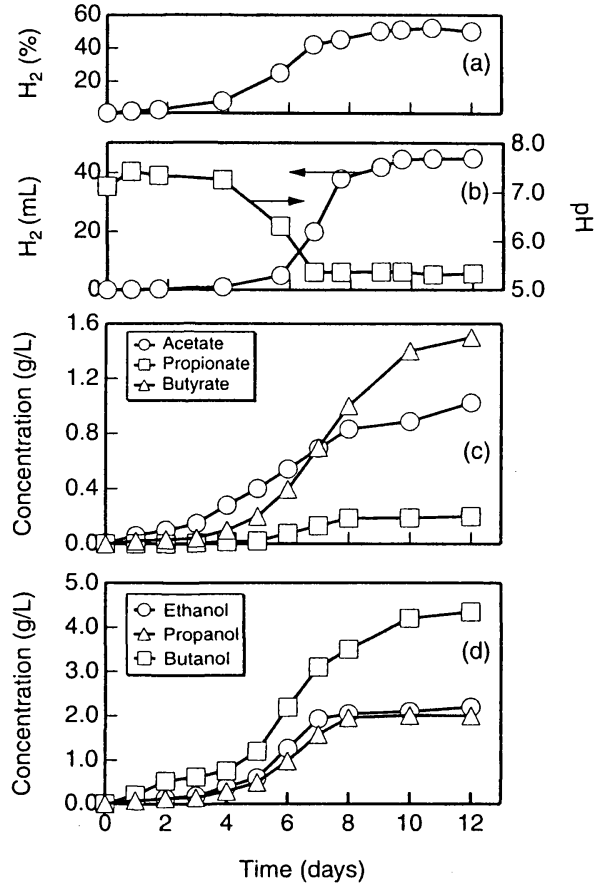

Fig.1 Hydrogen production and metabolites in batch degradation of $25.0 \mathrm{~g} / \mathrm{L}$ cellulose: (a) composition of hydrogen in biogas, (b) cumulative hydrogen production and $\mathrm{pH}$, (c) volatile fatty acids (i.e., acetate, propionate and butyrate), and (d) alcohols (i.e., ethanol, propanol and butanol).

converting cellulose into hydrogen possessed a partial clostridial characteristics in this study.

\section{(3) Characteristics of the sludge transferring cellulose into hydrogen}

In this study, lag-period time represented the period of a free spore complete transferring into a fully active vegetative cell and cellulose degraded into soluble hydrogen/metabolites because the lag-period time of cellulose digestion is highly correlated with viable cell number ${ }^{39}$. Specific molar hydrogen/metabolites production rate and potential represented bacterial activity and capability on the formation of hydrogen/ metabolites, respectively.

\section{(a) Lag-period time}

Lag-period times of the digested sludge converting cellulose into hydrogen, VFAs and alcohols were estimated using Eq. (1) and listed in Table 1. To relate lag-period time to the microorganisms reversion, production lag-period times of hydrogen, acetate, propionate, butyrate, ethanol, propanol and butanol were found to change with initial cellulose concentrations (Fig.2). Results in Fig.2 indicate that the lag-period time of hydrogen production increased from 3.8 to $4.4 \pm 0.1$ days while the cellulose 


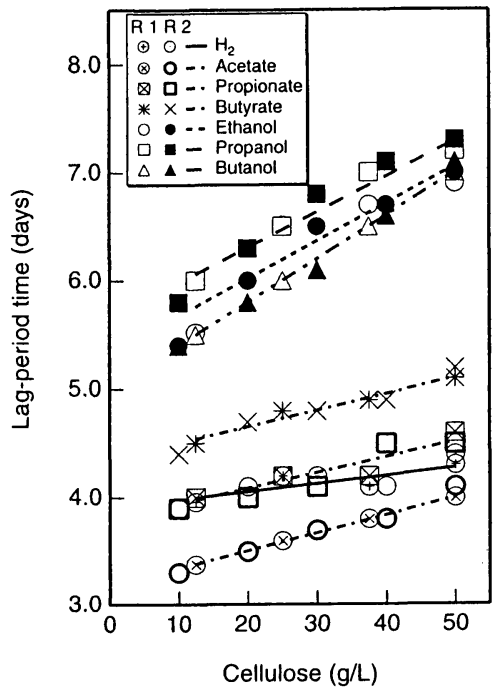

Fig.2 Production lag-period times of hydrogen, VFAs and alcohols while the inhibited digested sludge consuming various cellulose concentrations. R 1 and $\mathrm{R} 2$ represent run 1 and run 2 , respectively.

concentration increasing from 10.0 to $50.0 \mathrm{~g} / \mathrm{L}$. The same trend of lag-period time was also occurred at the VFAs and solvents against cellulose concentrations, increasing from $3.9 \pm 0.6$ to $4.6 \pm 0.5$ days and $5.5 \pm$ 0.2 to $7.1 \pm 0.2$ days, respectively. In this study, because the same quantity of seed sludge was used in each vial, the change of lag-period time was mainly caused by the change of cellulose concentration. Consequently, the production lag-period times of hydrogen and metabolites were dependent on initial cellulose concentration. This result is in agreement with Giallo et al.' $\mathrm{s}^{15)}$ observations for Clostridium cellulolyticm $\mathrm{H} 10$ consuming cellulose. Experimental results of Ueno et al. ${ }^{16)}$ also demonstrates that hydrogen production from the anaerobic digested sludge and the sludge compost consuming cellulose powder began to occur gradually after around one and three days, respectively. The latter presumably has a higher number of anaerobic spore-forming bacteria than that of the former due to the fact that the bacteria were not deactivated during aeration in the rapid composting.

\section{(b) Production rate}

Fig.3 shows the relation between the estimating specific production rates of hydrogen and metabolites using Eq. (1) and the cellulose concentrations. An examination of the data in Fig.3a reveals that specific hydrogen production rate increased from 8.02 to 11.16 $\mathrm{mmol} / \mathrm{gVSS} / \mathrm{d}$ while the cellulose concentrations from 10.0 to $25.0 \mathrm{~g} / \mathrm{L}$. However, it dropped to $2.54 \mathrm{mmol} /$ $\mathrm{gVSS} / \mathrm{d}$ when the concentration exceeded $25.0 \mathrm{~g} / \mathrm{L}$. Again, development of specific VFAs production rates (Fig.3b) were observed in parallel with that of hydrogen

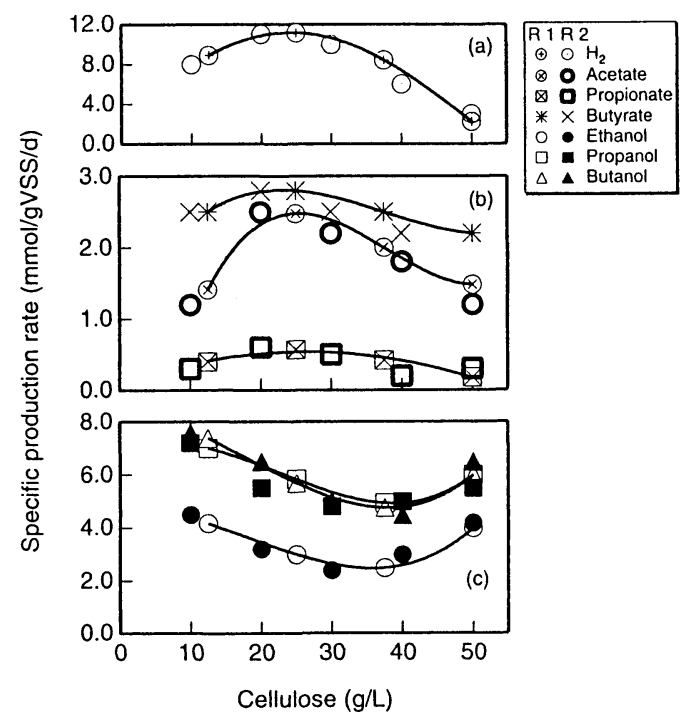

Fig.3 Specific production rates of (a) hydrogen, (b) volatile fatty acids and (c) alcohols while the inhibited digested sludge consuming various cellulose concentrations. R 1 and $\mathrm{R} 2$ represent run 1 and run 2, respectively.

(Fig.3a). It was obvious that alternation of the sludge activity on the VFAs formations accompanied/followed that of hydrogen production. The decrease in hydrogen production rate (Fig.3a) might tentatively be influenced by cellulolysis products, such as soluble sugars and hydrogen. Although no significant evidence could explain this phenomenon, an invert relationship was obtained between specific production rates of hydrogen/ VFAs and solvents. This relation suggest that $25.0 \mathrm{~g} / \mathrm{L}$ of cellulose might represent a threshold limit for the digested sludge shifting hydrogen/VFAs productions into alcohols production. It also implied that hydrogen played a more important role than soluble sugars on cellulose-degrading microorganisms during the exponential growth phase, which is in agreement with the Chung's study ${ }^{40}$. Hydrogen gas is a significant inhibitor on the growth of hydrogen-producing Clostridium cellobioparum. This barrier also limits the biological hydrogen production on a commercial scale ${ }^{41)}$ although hydrogen has been generated from corn pulp ${ }^{29)}$ and OFMSW ${ }^{26)}$ on a very small scale.

\section{(c) Production potential}

Fig. 4 shows the production potential of hydrogen, VFAs and alcohols, estimated using Eq. (1), for nine cellulose concentrations. An examination of Fig.4 shows that all potentials decreased with increase in initial cellulose concentration and depicts that values of hydrogen production potential ranged from 30 to $120 \mathrm{~mL} / \mathrm{gCOD}_{\text {cellulose}}$, whereas the value of $120 \mathrm{~mL} /$ $\mathrm{gCOD}_{\text {cellulose }}$ was close to $137 \mathrm{~mL} \mathrm{H}_{2} \mathrm{~mL} / \mathrm{gCOD}_{\text {glucose }}$ by using the inocula taken from compost ${ }^{6}$. Because the biogas was removed after the biogas measurement 


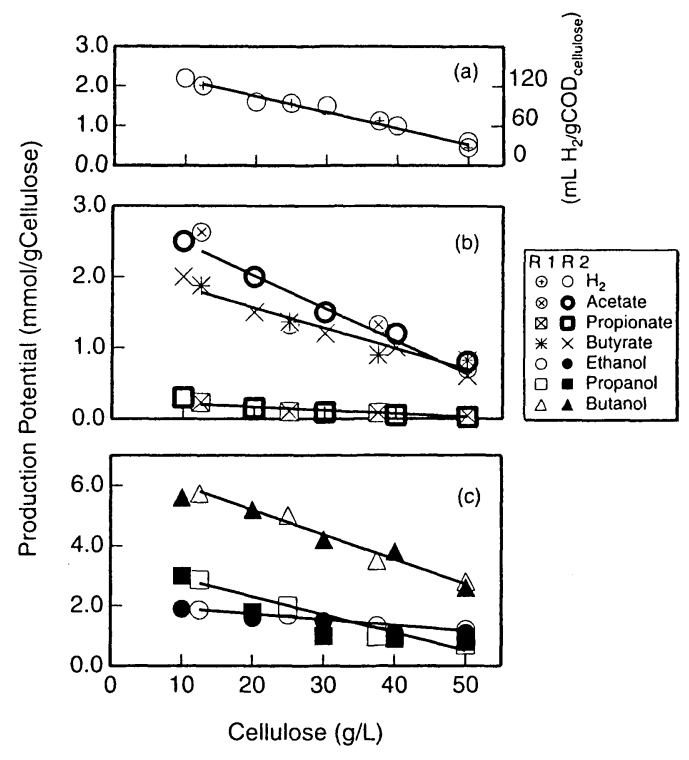

Fig.4 Specific production potential of (a) hydrogen, (b) volatile fatty acids and (c) alcohols while the inhibited digested sludge consuming various cellulose concentrations. R 1 and $\mathrm{R} 2$ represent run 1 and run 2 , respectively.

on each individual digester, the decrease in all potentials might be resulting from a decrease in $\mathrm{pH}$ or from soluble sugars accumulation ${ }^{42)-44)}$. In this study, no significant difference of the resulting final $\mathrm{pH}$ expressions when employing various cellulose concentrations was observed for hydrogen production. However, residual soluble carbohydrates in the samples of 10.0 and $12.5 \mathrm{~g} / \mathrm{L}(0.5 \pm 0.1 \mathrm{~g} / \mathrm{L})$ were clearly lower than those of $50.0 \mathrm{~g} / \mathrm{L}(1.4 \pm 0.4 \mathrm{~g} / \mathrm{L})$. It was assumed that the limitation of final production potentials would be more noticeable with soluble carbohydrates as substrates rather than cellulose. This suggestion is similar to Clostridium cellulolyticum $\mathrm{H} 10$ on the consumption of the soluble cellulose ${ }^{15)}$. Residual sugars in the supernatants increase with increase in initial soluble cellulose concentration.

In order to facilitate examination of relation among the main metabolites (hydrogen, VFAs and alcohols) within the sludge degrading the cellulose, the data listed in Table 1 were used. When ratios of acids to alcohols were plotted against their respective hydrogen production potentials, outside of one data point, the ratio depended linearly upon the yield of hydrogen production (Fig.5).

$$
\begin{gathered}
\text { Ratio }=0.2971+0.0783 \cdot \text { Hydrogen production } \\
\left(r^{2}=0.9547\right)
\end{gathered}
$$

Consider the fitted results graphed in Fig.5. The digested sludge transferring the cellulose into hydrogen might shift fermentation pattern from VFAs to alcohols. This metabolism was similar to that of pure culture of Clostridium sp. consuming carbohydrates ${ }^{36)-38)}$ where

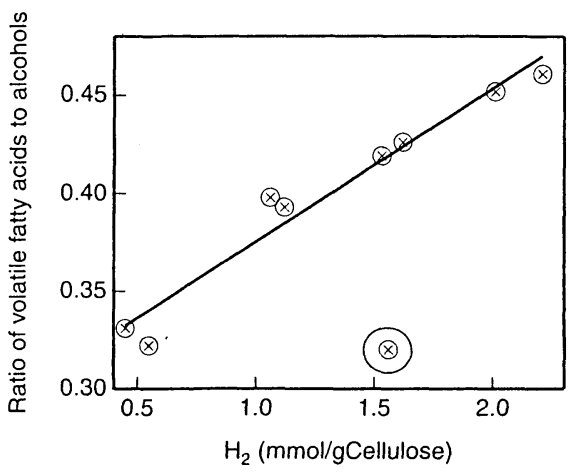

Fig.5 A plot of the production potential ratio of volatile fatty acids to alcohols against their respective hydrogen production potential. Circled data not included in linear regression analysis.

alcohol is a main product in the metabolism of hydrogen fermentation, and the microorganism forms VFAs during the exponential growth phase. Only during the late growth phase does the metabolism shift to rapid solvent production.

\section{SUMMARY AND CONCLUSIONS}

Cellulose is an important component in organic waste. Conversion of cellulose to hydrogen by microbial fermentation has a considerable potential to reduce organic waste accumulation and hydrocarbon fuels supply. A large number of hydrogen-producing microorganisms usually contain in anaerobic digested sludge; however, only traces of hydrogen are evolved with continuous flow digesters due to the ubiquitous nature of hydrogen consumers. For efficient industrial use, anaerobic mesophilic digested sludge pretreated with boiling water for inhibiting the activity of hydrogentrophic bacteria were performed to degrade microcrystalline cellulose. The experimental results emphasized effect of cellulose concentration on hydrogen and metabolites productions. Based on the results and discussion, the principle conclusions derived from this investigation are as follow:

(1) According to statistical analysis on the batch experiments, the inhibited digested sludge had a high stability and the results measured in this study possessed a high reliability.

(2) The generation pattern of hydrogen, VFAs and alcohols indicates that the heat-pretreated digested sludge on converting the cellulose into hydrogen possessed a clostridial characteristics.

(3) The production lag-period times of hydrogen and metabolites increased with increase in cellulose concentrations, indicating that the lag-period times were dependent on initial cellulose concentration.

(4) The metabolism shifted from hydrogen/VFAs production to solvent production during the 
cellulose exceeding $25 \mathrm{~g} / \mathrm{L}$, while the role of hydrogen was concluded to be more important than that of soluble sugars within the bacterial exponential growth phase.

(5) Except for initial cellulose concentration, the limitation of the production potentials of hydrogen, VFAs and solvents would be more noticeable with soluble carbohydrates as substrates rather than cellulose.

ACKNOWLEDGMENTS: This work was supported by CREST (Core Research for Evolutional Science and Technology) of Japan Science and Technology (JST). Dr. Jiunn-Jyi Lay was a researcher of JST when this research work was conducted. The writers would also like to thank M. Koike for her editorial assistance.

\section{REFERENCES}

1) Gregoire-Padró, C.E.: Hydrogen, the once and future fuel, Energy \& Fuels, Vol.12, No.1, pp.1-2, 1998.

2) Maugh II, T.H.: Hydrogen: synthetic fuel of the future, Science, Vol.178, pp.849-852, 1972.

3) Gregory, D.P.: The hydrogen economy. A case is made for an energy regime in which all energy sources would be used to produce hydrogen, which could then be distributed as a nonpolluting multipurpose fuel, Scient. Am., Vol.228, No.1, pp.13-21, 1973.

4) Zajic, J.E., Kosaric, N. and Brosseau, J.D.: Microbial production of hydrogen, Adv. Biochem. Eng., Vol.7, pp.57109, 1978.

5) Rajeshwar, K., Ibanez, J.G. and Swain, G.M.: Electrochemistry and the environment, J. Appl. Electrochem., Vol.24, pp.1077-1091, 1994.

6) Gray, C.T. and Gest, H.: Biological formation of molecular hydrogen, Science, Vol.148, pp.186-191, 1965.

7) Borkris, J.O'M.: A hydrogen economy, Science, Vol.178, pp. 1323-1323, 1973.

8) Groff, K.A. and McLaughlin, L.A.: Sludge management, Wat. Environ. Res., Vol.66, No.4, pp.368-375, 1994.

9) Lay, J.J., Li, Y.Y. and Noike, T.: A mathematical model for methane production from a landfill bioreactor, J. Envir. Engrg., ASCE., Vol.124, No.8, 1998.

10) Cecchi, F., Traverso, P.G., Mata-Alvarez, J., Clancy, J. and Zaror, C.: State of the art of R. \& D. in the anaerobic digestion process of municipal solid waste in Europe. Biomass, Vol. 16, pp.257-284, 1998.

11) Haug, R.T.: The practical handbook of compost engineering, Lewis Publishers, Tokyo, Chap. 8, 1993.

12) Eighmy, T.T. and Kosson, D.S.: U.S.A. national overview on waste management, Waste Mgmt., Vol.16, No.5/6, pp. 361-366, 1996.

13) Weimer, P.J. and Zeikus, J.G.: Fermentation of cellulose and cellobiose by Clostridium thermocellum in the absence and presence of Methanobacterium thermoautotrophicum, Appl. Environ. Microbiol., Vol.33, No.2, pp.289-297, 1977.

14) Zeikus, J.G.: Chemical and fuel production by anaerobic bacteria. Ann. Rev. Microbiol., Vol.34, pp.423-464, 1980.

15) Giallo, J., Gaudin, C. and Belaich, J.-P.: Metabolism and solubilization of cellulose by Clostridium cellulolyticum $\mathrm{H} 10$, Appl. Environ. Microbiol., Vol.49, No.5, pp.1216-1221,
1985.

16) Ueno, Y., Kawai, T., Sato, S. Otsuka, S. and Morimoto, M.: Biological production of hydrogen from cellulose by natural anaerobic microflora, J. Ferment. Technol., Vol.79, No.4, pp.395-397, 1995.

17) Schink, B.: Principles and limits of anaerobic degradation: environmental and technological aspects, Biological of Anaerobic Microorganisms, Zehnder, A.J.B. ed, John Wiley \& Sons, Singapore, pp.771-846, 1987.

18) van Haandel, A.C. and Lettinga, G.: Anaerobic sewage treatment, John Wiley \& Sons, New York. Chap. 2, 1994.

19) Guwy, A.J., Hawkes, F.R., Hawkes, D.L. and Rozzi, A.G.: Hydrogen production in a high rate fluidised bed anaerobic digester, Wat. Res., Vol.31, No.6, pp.1291-1298, 1997.

20) Fond, O., Petitdemange, E., Petitdemange, H., Engasser, J.M.: Cellulose fermentation by a coculture of a mesophilic cellulolytic Clostridium and Clostridium acetobutylicum. Biotechnol. Bioeng. Sym., Vol. 13, pp. 217-224, 1983.

21) Holmes, P. and Freischel, M.R.: $\mathrm{H}_{2}$-producing bacteria in digesting sewage sludge isolated on simple, defined media, Appl. Environ. Microbiol., Vol.36, No.2, pp.394-395, 1979.

22) Pavlostathis, S.G., Miller, T.L. and Wolin, M.J.: Fermentation of insoluble cellulose by continuous cultures of Ruminococcus albus., Appl. Environ. Microbiol., Vol.54, No.5, pp.26552569, 1991.

23) Sparling, R., Risbey, D. and Poggi-Varaldo, H.M.: Hydrogen production from inhibited anaerobic composters, Int. J. Hydrogen Energy, Vol.22, No.6, pp.563-566, 1997.

24) Talaro, K. and Talaro, A.: Foundations in microbiology, Wm. C. Brown Publishers, Chapt. 3, 1993.

25) van Andel, J.G., Zoutberg, G.R., Crabbendam, P.M. and Breure, A.M.: Glucose fermentation by Clostridium butyricum grown under a self generated gas atmosphere in chemostat culture, Appl. Microbiol. Biotechnol., Vol.23, pp. 21-26, 1985.

26) Lay, J.J., Lee, Y.J and Noike, T. : Feasibility of biological hydrogen production from organic fraction of municipal solid waste, Water Res., Vol.33, No.11, pp.2579-2586,1999.

27) Lay, J.J., Li, Y.Y. and Noike, T.: The influences of $\mathrm{pH}$ and moisture content on the methane production in high-solids sludge digestion, Wat. Res., Vol.31, No.6, pp.1518-1524, 1997.

28) Bahl, H., Andersch, W., Braun, K. and Gottschalk, G.: Effect of $\mathrm{pH}$ and butyrate concentration on the production of acetone and butanol by Clostridium acetobutylicum grown in continuous culture, Eur. J. Appl. Microbiol. Biotechnol., Vol. 14, pp.17-20, 1982.

29) Roychowdhury, S., Cox, D. and Levandowsky, M.: Production of hydrogen by microbial fermentation, Int. Hydrogen Energy, Vol.13, No.7, pp.407-410, 1988.

30) Owen, W.F., Stuckey, D.C., Healy Jr., J.B., Young, L.Y., McCarty, P.L.: Bioassay for monitoring biochemical methane potential and anaerobic toxicity, Wat. Res., Vol.13, pp.485493, 1979.

31) APHA: Standard methods for the examination of water and wastewater, 19th ed. American Public Health Association, Washington, DC, USA, 1995.

32) Microsoft Excel user guide; version 5.0: Microsoft Corporation, 1994

33) Wen, T.C., Cheng, S.S. and Lay, J.J.: A kinetic model of a recirculated upflow anaerobic sludge blanket treating phenolic wastewater, Wat. Environ. Res., Vol.66, No.6, pp.794-799, 1994.

34) Lay, J.J. and Cheng, S.S.: Influence of hydraulic loading rate 
on a UASB reactor treating phenolic wastewater, J. Envir. Engrg., ASCE., Vol. 124, No. 9, pp. 829-836, 1998.

35) Box, G.E.P., Hunter, W.G. and Hunter, J.S.: Statistics for experimenters. An introduction to design, data analysis, and model building, Wiley, New York, 1978.

36) Kim, B.H., Bellows, P., Datta, R. and Zeikus, J.G.: Control of carbon and electron flow in Clostridium acetobutylicum fermentation: utilization of carbon monoxide to inhibit hydrogen production and to enhance butanol yield, Appl. Environ. Microbiol., Vol.43, pp.1434-1439, 1984.

37) Brosseau, J.D., Yan, J.-Y. and Lo, K.V.: The relationship between hydrogen gas and butanol production by Clostridium saccharoperbutylacetonicum, Biotechnol. Bioeng., Vol.28, pp.305-310, 1986.

38) Grupe, H. and Gottschalk, G.: Physiological events in Clostridium acetobutylicum during the shift from acidogenesis to solventogenesis in continuous culture and presentation of a model for shift induction, Appl. Environ. Microbiol., Vol.58, No.12, pp.3896-3902, 1992.

39) Wells, J.E. and Russell, J.B.: The endogenous metabolism of
Fibrobacter succinogenes and its relationship to cellobiose transport, viability and cellulose digestion, Appl. Microbiol. Biotechnol., Vol.41, pp.471-476, 1994.

40) Chung, K.-T.: Inhibitory effects of $\mathrm{H}_{2}$ on growth of Clostridium cellobioparum. Appl. Environ. Microbiol., Vol. 31, No.3, pp.342-348, 1976.

41) Bollinger, R., Zurrer, M. and Bachofen, R.: Photoproduction of molecular hydrogen from waste water of a sugar refinery by photosynthetic bacteria, Appl. Microbiol. Biotechnol., Vol 23, pp.147-151, 1985.

42) Hungate, R.E.: The anaerobic mesophilic cellulolytic bacteria, Bacteriol. Rev., Vol.14, pp.1-49, 1950.

43) Gordon, J., Jiminez, M., Cooney, C.L. and Wang, D.I.C.: Sugar accumulation during enzyme hydrolysis and fermentation of cellulose, Am. Inst. Chem. Engineers. Symp. Ser., Vol.74, pp.91-97, 1978.

44) Liungdahl, L. and Eriksson, G.K.: Ecology of microbial cellulose degradation. Adv. Microb. Ecol., Vol.8, pp.237-245, 1985.

(Received June 1, 1998)

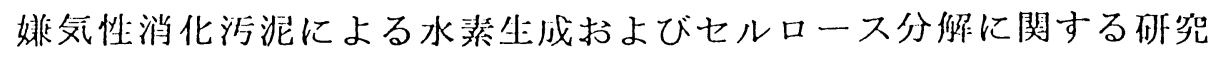

\section{頼俊吉 - 野池達也}

本研究は前処理された中温消化污泥による水类生成抢よび微結㫨セルロースの分解について, 回分果験によっ

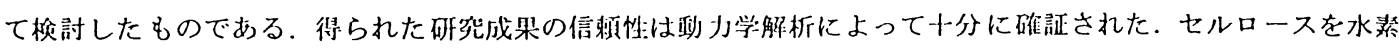

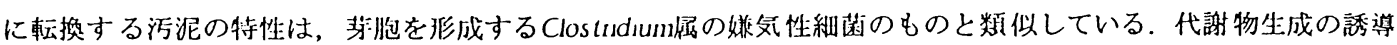

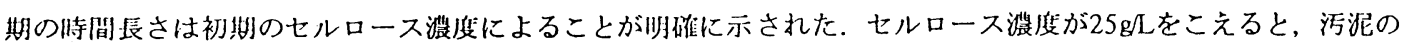

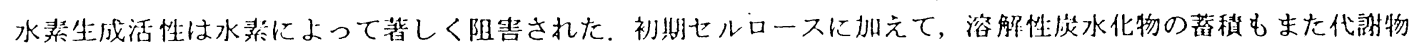
生成の替仼能力に影瑟をもたらす重要な姴因であることが明らかとなった。 